Brit. J. soc. Med. (1947), 1, 182-196.

\title{
DIETARIES IN MATERNITY HOSPITALS
}

\author{
BY \\ E. W. H. CRUICKSHANK, D.Sc., Ph.D., M.D. \\ AND \\ C. P. STEWART, M.Sc., Ph.D.
}

From the Department of Physiology, Marischal College, Aberdeen, and the Biochemical Laboratory, The Royal Infirmary, Edinburgh

Several comprehensive studies of hospital feeding have been planned to show as precisely as possible the nutritive value of representative diets provided in hospitals for patients and staff. The Scientific Advisory Committee of the Department of Health for Scotland has been carefully examining the problem of hospital diets and has made surveys and will publish a report in due course.

The purpose of this survey, which was carried out under the aegis of the SubCommittee on Nutrition of the Department of Health for Scotland, was to determine the nutritive value of diets provided to nursing mothers while in hospital. Fifteen hospitals were visited during the period February to August 1945; 8 were voluntary hospitals, and, of these, 2 were solely maternity hospitals; 5 were local authority hospitals, and, of these, 4 formed parts of general hospitals; and 2 were E.M.S. hospitals, both of these dealing only with maternity cases. Except for the north-west area of Scotland, the hospitals, urban and rural, were representative of the maternity hospital service in Scotland. The kitchens were of various sizes, the smallest catering for some 60 persons (staff and patients), the largest for 2,000. The results of the surveys show that there was no correlation between the dietary standard and the type of hospital, its size and location or the season of the year when the survey was made.

\section{MeTHODS}

Surveys were carried out throughout one week in each hospital. The ward containing the greatest number of beds was chosen, and when practicable more than one ward was included. Usually the wards contained both antenatal and postnatal patients but little differentiation, in most cases none at all, was found between the feeding of these two groups. All aspects of the catering service were observed, and particularly those concerning the condition of the food as it reached the patients.

\section{Hospital meals}

During the survey an extra diet was ordered each day for the ward concerned, and at every meal time a sample serving of each dish provided was chosen and the contents weighed. Bread, milk, tea, etc., were averaged daily on the individual 
intake of six or more patients at separate meals: general and plate wastage was observed. Calculations of carbohydrate, protein, animal protein, and fat in each day's diet were made: an estimation of mineral salts and vitamins was made from a daily average of the total intake of the various foods contained in the week's diet as a whole. Extras were checked by a detailed examination of a chosen number of patients in each ward.

"Extras"

Six patients were chosen: in each case, a record of the weight of foodstuffs already in the possession of individual patients was kept, and all additions that were made throughout the week. The amount of food wasted, given away, or otherwise disposed of, and also the amount which remained, were deducted at the end of the week and a daily average intake was calculated in each case. Finally, an average of the "extras" consumed by the six patients was taken.

\section{The basis of calculations}

The calculations of the various nutrients were made from the Medical Research Council's Nutritive Values of War-time Foods (War Memo. No. 14, 1944), and from The Chemical Composition of Foods (McCance and Widdowson, 1940). Vitamin C values are in every case the result of analyses by one of us (C.P.S.) of foods taken at the time of serving. Made up foods, and unknown and doubtful articles of diet, such as sausages, were analysed chemically, and the food values of soups, sauces, etc., were calculated from the actual quantities of the ingredients used in their preparation in the hospital kitchen.

\section{Standards of comparison}

In determining the adequacy of a diet the nutrient requirements of the community or group under examination must be estimated. In all dietary surveys the difficulty of determining a standard of comparison is ever present. Numerous dietary standards of required nutrients have been published, e.g. that suggested by the National Research Council, U.S.A. (1941), but this does not necessarily give the minimal amount compatible with health. Indeed it is now generally accepted that, as far as this country is concerned, the National Research Council requirements are in most cases well above the optimum for health. It should also be borne in mind that these requirements are for nursing mothers who are not confined to bed, that they are supplied by food as purchased, that, in following them, allowance has been made for losses in storage and preparation as well as in absorption and utilization of the foodstuff.

To arrive at a standard of comparison, a diet was devised which was regarded as possible within the existing conditions of food rationing and supply, and which would generally be accepted as good. The composition of the diet in terms of nutrients was calculated, and thus a reasonable target was adopted, the attainment of which was certainly possible for every maternity hospital. It should, however, be emphasized that the target represents the food consumed by the subject, that allowance has been made only for unavoidable losses, and that the attainment of 
such a target from the foods suggested demands a higher standard of preparation and cooking than that which generally obtains. The suggested diet is shown in Table I. The calculated average daily consumption of nutrients from the suggested

TABLE I

Suggested Maternity Diet.-Calculations based on the M.R.C. " Nutritive Value of War-time Foods"

\begin{tabular}{|c|c|c|c|c|c|c|c|c|c|c|c|c|}
\hline & $\begin{array}{l}\text { Aver- } \\
\text { age g. } \\
\text { per } \\
\text { day }\end{array}$ & $\begin{array}{c}\text { Calor- } \\
\text { ies }\end{array}$ & $\begin{array}{l}\text { Pro- } \\
\text { tein }\end{array}$ & Fat & Cho. & Ca. Mg. & Fe. Mg. & $\begin{array}{c}\text { Vita- } \\
\min A \\
\text { I.U. }\end{array}$ & $\begin{array}{l}\text { Thia- } \\
\text { min } \\
\mu \mathrm{g} .\end{array}$ & $\begin{array}{c}\text { Ribo- } \\
\text { flavin } \\
\mu \mathrm{g} .\end{array}$ & $\begin{array}{l}\text { Nico- } \\
\text { tinic } \\
\text { acid } \\
\text { mg. }\end{array}$ & $\begin{array}{c}\text { Vita- } \\
\text { min } \\
\text { C } \\
\text { mg. }\end{array}$ \\
\hline Milk $\quad .$. & 1,150 & 723 & $37 \cdot 0$ & $41 \cdot 4$ & $50 \cdot 6$ & $1,380 \cdot 0$ & $1 \cdot 15$ & 805 & 518 & 1,725 & $24 \cdot 0$ & 7 \\
\hline Margarine & 17 & 131 & - & $14 \cdot 5$ & - & & .05 & 340 & - & - & - & $\ldots$ \\
\hline Butter $\quad$. & 8 & 60 & - & $6 \cdot 6$ & - & $1 \cdot 2$ & .01 & 320 & - & - & - & - \\
\hline Cocoa & 6 & 26 & $1 \cdot 2$ & $1 \cdot 3$ & $1 \cdot 9$ & $3 \cdot 1$ & $\cdot 86$ & 3 & 7 & - & - & - \\
\hline Sugar & 32 & 115 & - & - & $30 \cdot 4$ & $0 \cdot 3$ & - & - & - & - & - & - \\
\hline $\left.\begin{array}{l}\text { Egg, tresh 10g. } \\
\text { dried } 10 \mathrm{~g} .\end{array}\right\}$ & 25 & 35 & $2 \cdot 8$ & $2 \cdot 5$ & $0 \cdot 2$ & $15 \cdot 0$ & .75 & 220 & 38 & 88 & $\cdot 10$ & - \\
\hline Bacon ... & 10 & 45 & $0 \cdot 8$ & $4 \cdot 7$ & - & 0.9 & .09 & - & 41 & 20 & $\cdot 11$ & - \\
\hline $\begin{array}{l}\text { Meat (rationed) } \\
\text { Bread, buns, etc. }\end{array}$ & 30 & 60 & $4 \cdot 8$ & $4 \cdot 5$ & - & $3 \cdot 0$ & $1 \cdot 10$ & 14 & 23 & 60 & $\cdot 36$ & - \\
\hline $\left.\begin{array}{r}150 \\
50\end{array}\right\}$ & 200 & 498 & $17 \cdot 2$ & $2 \cdot 0$ & $102 \cdot 8$ & $108 \cdot 0$ & $2 \cdot 40$ & - & 257 & 105 & .68 & - \\
\hline Cabbage, greens & 50 & 13 & 0.8 & - & $2 \cdot 5$ & $33 \cdot 0$ & .50 & 150 & 38 & 25 & .02 & 9 \\
\hline Semolina, etc. & 12 & 41 & $1 \cdot 3$ & 0.2 & $8 \cdot 3$ & $2 \cdot 2$ & $\cdot 12$ & - & 11 & 8 & .04 & - \\
\hline Flour $\quad$. . & 20 & 69 & $2 \cdot 4$ & 0.3 & $14 \cdot 2$ & $16 \cdot 4$ & $\cdot 32$ & - & 49 & 40 & .09 & - \\
\hline Potato & 160 & 117 & $3 \cdot 2$ & - & $25 \cdot \overline{9}$ & $12 \cdot 8$ & $1 \cdot 10$ & . & 192 & 80 & .32 & 16 \\
\hline Carrots & 20 & 4 & $0 \cdot \overline{1}$ & - & 1.0 & $9 \cdot 6$ & $\cdot 12$ & 1,333 & 12 & 10 & .04 & 1 \\
\hline Turnips & 15 & 3 & 0.1 & - & 0.5 & $8 \cdot 9$ & .06 & - & 5 & 8 & .03 & 2 \\
\hline Cheese & 8 & 29 & $1 \cdot 8$ & $2 \cdot 5$ & - & $58 \cdot 0$ & .05 & 104 & 2 & 40 & - & - \\
\hline Jam & 16 & 40 & - & - & $9 \cdot 9$ & 1.9 & - & 1 & - & - & - & 1 \\
\hline Oatmeal . & 28 & 109 & $3 \cdot 3$ & $2 \cdot 4$ & $18 \cdot 3$ & $15 \cdot 4$ & $1 \cdot 14$ & - & 126 & 8 & $\cdot 08$ & - \\
\hline Cooking fat & 13 & 116 & $0 \cdot 1$ & $12 \cdot 9$ & - & - & .01 & - & - & - & - & - \\
\hline Beans, peas & 20 & 58 & $4 \cdot 4$ & - & $10 \cdot 2$ & $6 \cdot 6$ & 1.08 & 13 & 90 & 60 & .02 & - \\
\hline Fish $\int$ fatty & 20 & 27 & $3 \cdot 2$ & $1 \cdot 6$ & & $20 \cdot 0$ & $\cdot 30$ & 30 & 2 & 30 & $\cdot 16$ & - \\
\hline Fish $\left\{\begin{array}{l}\text { white } \\
\text { w }\end{array}\right.$ & 20 & 14 & $3 \cdot 2$ & 0. & - & $5 \cdot 0$ & $\cdot 20$ & - & 12 & 30 & .10 & - \\
\hline Raisins $\quad .$. & 4 & 8 & - & - & $2 \cdot 3$ & $2 \cdot 4$ & .06 & 1 & - & 1 & .01 & - \\
\hline & 8 & 11 & 0.2 & - & $2 \cdot 6$ & $2 \cdot 7$ & $\cdot 12$ & 66 & - & 2 & $\cdot 16$ & - \\
\hline & 4 & 13 & $0 \cdot \overline{3}$ & $0 \cdot 1$ & $2 \cdot 9$ & 0.4 & .03 & - & 3 & 3 & .01 & - \\
\hline Macaroni .. & 6 & 20 & 0.6 & $0 \cdot 1$ & $4 \cdot 2$ & $1 \cdot 6$ & .08 & - & 5 & - & .02 & - \\
\hline Spam $\quad$. & 9 & 23 & $1 \cdot 4$ & 1.9 & - & 0 . & $\cdot 18$ & - & 40 & 3 & .06 & - \\
\hline Bridie $\quad \ldots$ & 14 & 51 & $1 \cdot 5$ & $3 \cdot 2$ & $3 \cdot 9$ & $2 \cdot 1$ & $\cdot 28$ & - & 14 & 2 & .07 & - \\
\hline Black pudding & 9 & 23 & 0.9 & $1 . \overline{6}$ & $1 \cdot 2$ & $2 \cdot 7$ & .09 & - & 15 & 6 & .05 & - \\
\hline Sausage $\quad .$. & 9 & 23 & 0.9 & $1 \cdot 6$ & $1 \cdot 2$ & $2 \cdot 7$ & .09 & - & 15 & 6 & .05 & - \\
\hline e (or other offal) & 16 & 13 & $2 \cdot 4$ & 0.7 & - & $1 \cdot 2$ & .28 & - & 4 & 12 & $\cdot 13$ & - \\
\hline Rabbit .. & 16 & 13 & $2 \cdot 4$ & 0.7 & - & $1 \cdot \overline{2}$ & .28 & - & 4 & 12 & .13 & - \\
\hline Baked beans & 14 & 12 & 0.8 & - & $2 \cdot 2$ & $7 \cdot 7$ & .35 & 23 & 8 & 5 & .03 & - \\
\hline Stewed apple & 12 & 2 & - & - & $\overline{0} \cdot \overline{5}$ & $0 \cdot 2$ & .01 & 6 & 5 & - & - & - \\
\hline Onion $\quad$. & 6 & 1 & - & - & $0 \cdot 3$ & $1 \cdot \overline{6}$ & .02 & - & 1 & - & - & - \\
\hline Totals & & 2,546 & $99 \cdot 1$ & $107 \cdot 6$ & $298 \cdot 0$ & $1,729 \cdot 4$ & $13 \cdot 28$ & 3,429 & 1,537 & 2,389 & .27 & 36 \\
\hline
\end{tabular}

NoTES

Bread: taken as $150 \mathrm{~g}$. bread plus $50 \mathrm{~g}$. buns calculated as bread except for thiamin and riboflavin, which are taken as $50 \%$ of the bread figure.

Milk: Vitamin A--winter figure used.

Butter: calculated at 2,000 I.U. Vitamin A per $100 \mathrm{~g}$.

Thiamin: $15 \%$ of total allowed for cooking losses, etc.

Vitamin C: cooking losses taken as $75 \%$ for green vegetables and $50 \%$ for other vegetables.

Thiamin: $1,537 \mu \mathrm{g}$. less $15 \%-1,306 \mu \mathrm{g} .=1 \cdot 3 \mathrm{mg}$. 
MENU FOR WeEK

\begin{tabular}{|c|c|c|c|c|c|c|}
\hline Monday & Tuesday & Wednesday & Thursday & Friday & Saturday & Sunday \\
\hline $\begin{array}{l}\text { BREARFAST } \\
\text { Porridge and } \\
\quad \text { Milk } \\
\text { Bacon } \\
\text { Fried bread } \\
\text { Bread and } \\
\text { margarine } \\
\text { Tea }\end{array}$ & $\begin{array}{l}\text { Porridge and } \\
\text { Milk } \\
\text { Herring } \\
\text { Marmalade } \\
\text { Bread and } \\
\text { margarine } \\
\text { Tea }\end{array}$ & $\begin{array}{l}\text { Ponidge and } \\
\text { Milk } \\
\text { Omelette } \\
\text { (dried egg) } \\
\text { Bread and } \\
\text { margarine } \\
\text { Tea }\end{array}$ & $\begin{array}{l}\text { Porridge and } \\
\text { Milk } \\
\text { Bacon } \\
\text { Bread and } \\
\text { margarine } \\
\text { Tea }\end{array}$ & $\begin{array}{l}\text { Porridge and } \\
\quad \text { Milk } \\
\text { Sausage } \\
\text { Bread and } \\
\text { margarine } \\
\text { Tea }\end{array}$ & $\begin{array}{l}\text { Porridge and } \\
\text { Milk } \\
\text { Black pud- } \\
\text { ding } \\
\text { Marmalade } \\
\text { Bread and } \\
\text { margarine } \\
\text { Tea }\end{array}$ & $\begin{array}{l}\text { Porridge and } \\
\text { Milk } \\
\text { Egg, boiled, } \\
\text { etc. } \\
\text { Bread and } \\
\text { margarine } \\
\text { Tea }\end{array}$ \\
\hline $\begin{array}{l}\text { MID-MORN- } \\
\text { ING } \\
\text { Milk or milk } \\
\text { shake } \\
\text { Bun or bis- } \\
\text { cuit }\end{array}$ & $\begin{array}{l}\text { Milk or milk } \\
\text { shake } \\
\text { Bun or bis- } \\
\text { cuit }\end{array}$ & $\begin{array}{l}\text { Milk or milk } \\
\text { shake } \\
\text { Bun or bis- } \\
\text { cuit }\end{array}$ & $\begin{array}{l}\text { Milk or milk } \\
\text { shake } \\
\text { Bun or bis- } \\
\text { cuit }\end{array}$ & $\begin{array}{l}\text { Milk or milk } \\
\text { shake } \\
\text { Bun or bis- } \\
\text { cuit }\end{array}$ & $\begin{array}{l}\text { Milk or milk } \\
\text { shake } \\
\text { Bun or bis- } \\
\text { cuit }\end{array}$ & $\begin{array}{l}\text { Milk or milk } \\
\text { shake } \\
\text { Bun or bis- } \\
\text { cuit }\end{array}$ \\
\hline $\begin{array}{l}\text { DiNNER } \\
\text { Vegetable } \\
\quad \text { broth } \\
\text { Stewed } \\
\quad \text { rabbit } \\
\text { Carrot, } \\
\text { turnip } \\
\text { Onion } \\
\text { Beans/peas } \\
\text { Potato } \\
\text { Semolina } \\
\text { Stewed apple } \\
\text { Milk }\end{array}$ & $\begin{array}{l}\text { Split pea } \\
\text { soup } \\
\text { Spam } \\
\text { Green salad, } \\
\text { etc., or } \\
\text { cooked } \\
\text { greens } \\
\text { Potato } \\
\text { Steamed } \\
\text { jam or } \\
\text { syrup } \\
\text { pudding } \\
\text { Custard } \\
\text { Milk }\end{array}$ & $\begin{array}{l}\text { Potato soup } \\
\text { Mince } \\
\text { Cabbage } \\
\text { Potato } \\
\text { Semolina/ } \\
\text { prunes } \\
\text { Milk. }\end{array}$ & $\begin{array}{l}\text { Brown vege- } \\
\text { table soup } \\
\text { Macaroni } \\
\text { cheese } \\
\text { Cauliflower } \\
\text { Potato } \\
\text { Chocolate } \\
\text { cornflour } \\
\text { pudding } \\
\text { Milk }\end{array}$ & $\begin{array}{l}\text { Bean/pea } \\
\text { soup } \\
\text { White fish } \\
\text { Parsley } \\
\text { sauce } \\
\text { Potato } \\
\text { Steamed } \\
\text { fruit } \\
\text { pudding } \\
\text { Custard } \\
\text { Milk } \\
\end{array}$ & $\begin{array}{l}\text { Vegetable } \\
\text { broth } \\
\text { Steak pie } \\
\text { Brussels } \\
\text { sprouts } \\
\text { Potato } \\
\text { Custard } \\
\text { padding } \\
\text { Milk }\end{array}$ & $\begin{array}{l}\text { Barley soup } \\
\text { Roast beef } \\
\text { or mutton } \\
\text { Cabbage } \\
\text { Potato } \\
\text { Semolina } \\
\text { Raisin } \\
\text { pudding } \\
\text { Milk }\end{array}$ \\
\hline $\begin{array}{l}\text { TEA } \\
\text { Bread and } \\
\text { butter } \\
\text { Scone or bun } \\
\text { Jam } \\
\text { Tea }\end{array}$ & $\begin{array}{l}\text { Bread and } \\
\text { butter } \\
\text { Scone or bun } \\
\text { Madeira } \\
\text { cake } \\
\text { Tea }\end{array}$ & $\begin{array}{l}\text { Bread and } \\
\text { butter } \\
\text { Scone or bun } \\
\text { Jam } \\
\text { Tea }\end{array}$ & $\begin{array}{l}\text { Bread and } \\
\text { butter } \\
\text { Scone or bun } \\
\text { Sponge cake } \\
\text { Tea }\end{array}$ & $\begin{array}{l}\text { Bread and } \\
\text { butter } \\
\text { Scone or bun } \\
\text { Jam } \\
\text { Tea }\end{array}$ & $\begin{array}{l}\text { Bread and } \\
\quad \text { butter } \\
\text { Scone or bun } \\
\text { Fruit cake } \\
\text { Tea }\end{array}$ & $\begin{array}{l}\text { Bread and } \\
\text { butter } \\
\text { Scone or bun } \\
\text { Gingerbread } \\
\text { Tea }\end{array}$ \\
\hline $\begin{array}{l}\text { SUPPER } \\
\text { Shepherd's } \\
\text { pie } \\
\text { Bread and } \\
\text { margarine } \\
\text { Milk/cocoa }\end{array}$ & $\begin{array}{l}\text { Tripe (or } \\
\text { offal) } \\
\text { Bread and } \\
\text { margarine } \\
\text { Coffee } \\
\text { blanc- } \\
\text { mange }\end{array}$ & $\begin{array}{l}\text { Bridie } \\
\text { Baked } \\
\text { potatoes } \\
\text { or chips } \\
\text { Bread and } \\
\text { margarine } \\
\text { Milk/cocoa }\end{array}$ & $\begin{array}{l}\text { Baked beans } \\
\text { Roast } \\
\text { potatoes } \\
\text { Bread and } \\
\text { margarine } \\
\text { Milk }\end{array}$ & $\begin{array}{l}\text { Egg (fresh) } \\
\text { Bread and } \\
\text { margarine } \\
\text { Raspberry } \\
\text { blanc- } \\
\text { mange }\end{array}$ & $\begin{array}{l}\text { Welsh } \\
\text { rarebit } \\
\text { Bread and } \\
\text { margarine } \\
\text { Milk/cocoa }\end{array}$ & $\begin{array}{l}\text { Sardines } \\
\text { Salmon } \\
\text { Bread and } \\
\text { margarine } \\
\text { Chocolate } \\
\text { mould }\end{array}$ \\
\hline $\begin{array}{l}\text { LATE } \\
\text { EVENING } \\
\text { Milk/cocoa }\end{array}$ & Milk/cocoa & Milk/cocoa & Milk/cocoa & Milk/cocoa & Milk/cocoa & Milk/cocoa \\
\hline
\end{tabular}


diet is shown in Table II; this Table constitutes the target with the exception of the figure of 2,500 for calories. The following points concerning the nutrients suggested should be noted.

1. Calories. - The number of calories, 2,546 , or 2,500 per day as a round number, while lower than that suggested by the National Research Council for a lactating woman, represents approximately the amount of food which can be eaten by nursing mothers who are confined to bed. It has been found almost impossible to get hospital patients to eat a daily diet of 3,000 Calories.

TABLE II

\begin{tabular}{|c|c|c|c|c|}
\hline & & & $\begin{array}{l}\text { Calculated average daily } \\
\text { consumption of nutrients from } \\
\text { the suggested diet }\end{array}$ & $\begin{array}{l}\text { Recommended daily allow- } \\
\text { ance, Food and Nutrition } \\
\text { Board, National Research } \\
\text { Council }\end{array}$ \\
\hline $\begin{array}{l}\text { Calories .. } \\
\text { Carbohydrate } \\
\text { Protein ... } \\
\text { Animal protein } \\
\text { Fat } . . \\
\text { Calcium .. } \\
\text { Iron } \\
\text { Vitamin A } \\
\text { Thiamin .. } \\
\text { Riboflavin } \\
\text { Nicotinic acid } \\
\text { Ascorbic acid }\end{array}$ & $\begin{array}{l}\cdots \\
\cdots \\
\cdots \\
\cdots \\
\cdots\end{array}$ & 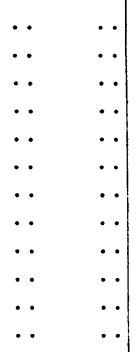 & 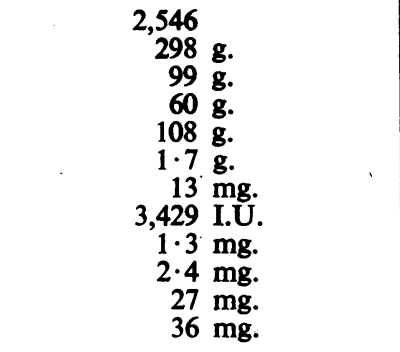 & $\begin{array}{c}3000 \\
100 \mathrm{~g} . \\
\overline{-} \\
\overline{2} \mathrm{~g} . \\
15 \mathrm{mg} . \\
8,000 \mathrm{I} . \mathrm{U} . \\
2 \cdot 3 \mathrm{mg} . \\
3.0 \mathrm{mg} . \\
23 \mathrm{mg} . \\
150 \mathrm{mg} .\end{array}$ \\
\hline
\end{tabular}

2. Protein.-The target figure for animal protein, $60 \mathrm{~g}$. per head per day, is essentially a sound requirement.

3. Vitamins.-Vitamin A.-The content of Vitamin A, 3,429 I.U. per head per day, is but half the N.R.C. figure. It could easily be increased, e.g. 2 oz. of sheep's liver per week would raise the figure to the region of 6,000 I.U. per day. The difficulty of obtaining liver today simply rules liver out of such a target dièt.

Thiamin $\left(B_{1}\right)$. - The target of $1.3 \mathrm{mg}$. per head per day is regarded as ample for women living under hospital conditions.

Vitamin C.-In view of the N.R.C. requirement of $150 \mathrm{mg}$. per head per day, the target figure, $36 \mathrm{mg}$. per head per day may be regarded as wholly inadequate. Details of the survey certainly show how low is the intake of vitamin C. Recent work on vitamin $\mathrm{C}$ requirements has enforced a revision of our ideas as to what is an adequate intake of this vitamin: $36 \mathrm{mg}$. of ascorbic acid per day are regarded as adequate for nursing mothers under hospital conditions. There are no reasons why this amount should not be secured within the range of an ordinary diet. This corresponds to about $100 \mathrm{mg}$. per day in the "as purchased" basis, since a combined wastage and cooking loss may amount to $60 \%$. 


\section{TOTAL FoOd Consumption}

This includes food supplied by the hospital and the relatives and friends of the patients.

\section{Calories}

The mean for all hospitals was 2,284 Calories, not very far below the suggested target of 2,500 Calories. The range was considerable, from 1,901 Calories in a large urban hospital with over 200 maternity beds, to 2,679 Calories in a rural hospital of 30 maternity beds. This cannot be regarded as indicating that rural hospitals are always better off than the city hospitals, because one rural hospital supplied 2,206, and a small town hospital 2,071, and a large city hospital 2,508 Calories per head per day (Table III). With respect to total calories, of nine large

TABLE III

Calories and Protein in Diets in Maternity Wards of Scottish Hospitals Target: Calories $=2,500$. Protein $=99$ g. Animal Protein $=60$ g.

\begin{tabular}{c|c|c|c|c|c|c}
\hline \multirow{2}{*}{ No. } & \multicolumn{2}{|c|}{ Total food consumption } & \multicolumn{2}{c|}{ Food supplied by hospital } \\
\cline { 5 - 7 } & Calories & $\begin{array}{c}\text { Total } \\
\text { protein }\end{array}$ & $\begin{array}{c}\text { Animal } \\
\text { protein }\end{array}$ & Calories & $\begin{array}{c}\text { Total } \\
\text { protein }\end{array}$ & $\begin{array}{c}\text { Animal } \\
\text { protein }\end{array}$ \\
\hline 1 & 2,508 & 88 & 46 & 1,941 & 78 & 46 \\
2 & 2,114 & 79 & 39 & 1,690 & 69 & 39 \\
3 & 2,321 & 79 & 40 & 1,829 & 70 & 40 \\
4 & 2,054 & 68 & 34 & 1,615 & 60 & 34 \\
5 & 1,901 & 78 & 43 & 1,648 & 73 & 43 \\
6 & 2,357 & 70 & 28 & 1,495 & 58 & 28 \\
7 & 2,110 & 84 & 48 & 1,929 & 81 & 48 \\
8 & 2,625 & 107 & 54 & 2,270 & 100 & 54 \\
9 & 2,363 & 81 & 42 & 2,173 & 79 & 42 \\
10 & 2,435 & 86 & 47 & 1,894 & 76 & 47 \\
11 & 2,212 & 80 & 36 & 1,695 & 68 & 36 \\
12 & 2,071 & 76 & 42 & 1,845 & 70 & 42 \\
13 & 2,310 & 84 & 45 & 2,054 & 77 & 45 \\
14 & 2,679 & 93 & 50 & 2,647 & 91 & 50 \\
15 & 2,206 & 79 & 38 & 1,986 & 76 & 38 \\
\hline Average & 2,284 & $82 \cdot 1$ & $42 \cdot 1$ & 1,914 & $75 \cdot 1$ & $42 \cdot 1$ \\
\hline
\end{tabular}

city hospitals only one was above the target; of the smaller towns and rural hospitals, two out of six were above the target. Since practically all the beds in our maternity hospitals are occupied, it is of interest to note the number of patients who, in large city and small town and rural hospitals, are supplied with a diet which, in terms of energy, is above or below the number of required calories. The number of beds in the maternity wards of the large city hospitals was 610, in the smaller towns and rural hospitals 263 (see Table IV). Out of 610 patients in the large city hospitals, 68 were above, 542 below the average in calories, i.e. 11.1 and $88.9 \%$ respectively. Out of the 263 patients in smaller towns and rural area hospitals, 60 were above, 203 below the target for calories, i.e. $22 \cdot 8$ and $77 \cdot 2 \%$ respectively. Therefore, on the assumption that all the beds were occupied, it is 
apparent that out of a total of 873 patients, 745 or $85.3 \%$ were below, and 128 or $14.7 \%$ were above the calorie target (Table IV).

Protein.-The standard of comparison demands $99 \mathrm{~g}$. of total protein and $60 \mathrm{~g}$. of animal protein per head per day; the average figures were $82.1 \mathrm{~g}$. and

TABLE IV

Table showing the Number of Beds in Hospitals in which the Diet supplied by Hospital and Patients is above or Below the Calorie Requirement The Target for Calories $=2.500$.

\begin{tabular}{|c|c|c|c|c|c|}
\hline \multicolumn{3}{|c|}{ Large cities } & \multicolumn{3}{|c|}{ Small towns and rural areas } \\
\hline No. & Above & Below & No. & Above & Below \\
\hline \multirow[t]{2}{*}{$\begin{array}{r}1 \\
2 \\
3 \\
4 \\
5 \\
6 \\
9 \\
10 \\
11\end{array}$} & . & $\begin{array}{r}40 \\
90 \\
60 \\
205 \\
30 \\
38 \\
43 \\
36\end{array}$ & $\begin{array}{r}7 \\
8 \\
12 \\
13 \\
14 \\
15\end{array}$ & $\begin{array}{l}30 \\
30^{*}\end{array}$ & $\begin{array}{r}24 \\
66 \\
73 \\
40\end{array}$ \\
\hline & 68 & 542 & & 60 & 203 \\
\hline Total beds & ’ & & & & \\
\hline Per cent & $11 \cdot 1$ & 88.9 & - & $22 \cdot 8$ & $77 \cdot 2$ \\
\hline
\end{tabular}

Total above. $128=14 \cdot 7 \%$

Total below. $745=85 \cdot 3 \%$

* The only hospital supplied with a diet giving more than 2,500 calories.

TABLE V

Table showing the Number of Beds in Hospitals in Relation to Protein in the Diet Supplied BY THE HOSPITALS

The Target for Total Protein $=99 \mathrm{~g}$. All but one below.

The Target for Animal Protein $=60 \mathrm{~g}$. All below.

The number of beds in hospitals in which the animal protein of the diet is above or below 40g.

\begin{tabular}{|c|c|c|c|c|c|c|c|}
\hline \multicolumn{4}{|c|}{ Large cities } & \multicolumn{4}{|c|}{ Small towns and rural areas } \\
\hline No. & Above $40 \mathrm{~g}$. & No. & Below $40 \mathrm{~g}$. & No. & Above $40 \mathrm{~g}$. & No. & Below $40 \mathrm{~g}$. \\
\hline \multirow[t]{2}{*}{$\begin{array}{r}1 \\
3 \\
5 \\
9 \\
10\end{array}$} & $\begin{array}{r}68 \\
90 \\
205 \\
38 \\
43\end{array}$ & $\begin{array}{r}2 \\
4 \\
6 \\
11\end{array}$ & $\begin{array}{l}40 \\
60 \\
30 \\
36\end{array}$ & $\begin{array}{r}7 \\
8 \\
12 \\
13 \\
14\end{array}$ & $\begin{array}{l}24 \\
30 \\
66 \\
73 \\
30\end{array}$ & 15 & 40 \\
\hline & 444 & & 166 & & .223 & & 40 \\
\hline Total & \multicolumn{3}{|c|}{610} & \multicolumn{4}{|c|}{263} \\
\hline $\begin{array}{l}\text { Per- } \\
\text { centage }\end{array}$ & $72 \cdot 8$ & & $27 \cdot 2$ & & $84: 7$ & & $15 \cdot 3$ \\
\hline
\end{tabular}

Total above 40 g. $\quad 667=76 \cdot 4 \%$

Total below $40 \mathrm{~g} . \quad 206=23 \cdot 6 \%$ 
$42 \cdot 1 \mathrm{~g}$. per head per day respectively. The range for total protein was 68 to $107 \mathrm{~g}$. per day, one hospital only exceeding the target; for animal protein the range was 28 to $54 \mathrm{~g}$. per head per day. The deficiency in total protein was $17 \%$, in animal protein it was $30 \%$; the latter is a very serious deficit.

Fat.-In this nutrient there was a $16 \%$ deficiency, which, in view of the nonactive life of the nursing mother in hospital, may be less seriously regarded; but nevertheless the fat deficiency, coupled with lack of animal protein, has been responsible for the monotony of our wartime dietaries.

Carbohydrate.-This, while generally adequate, could bear some increase (Table VI).

TABLE VI

Fat and Carbohydrate in Maternity Hospital Diets with the Average Daily amounts OF EACH SUPPLIED BY THE Hospital and Patient's Friends Fat $(g$.) Carbohydrate $(g)$.

Target $=108 \mathrm{~g}$. Target $=298 \mathrm{~g}$.

\begin{tabular}{|c|c|c|c|c|c|c|}
\hline & Hospital & $\begin{array}{l}\text { Patient's } \\
\text { friends }\end{array}$ & Total & Hospital & $\begin{array}{l}\text { Patient's } \\
\text { friends }\end{array}$ & Total \\
\hline $\begin{array}{r}1 \\
2 \\
3 \\
4 \\
5 \\
6 \\
7 \\
8 \\
9 \\
10 \\
11 \\
12 \\
13 \\
14 \\
15\end{array}$ & $\begin{array}{r}83 \\
59 \\
71 \\
65 \\
66 \\
42 \\
79 \\
90 \\
85 \\
76 \\
65 \\
78 \\
86 \\
114 \\
77\end{array}$ & $\begin{array}{r}21 \\
15 \\
16 \\
22 \\
7 \\
40 \\
7 \\
15 \\
5 \\
21 \\
22 \\
9 \\
12 \\
2 \\
8\end{array}$ & $\begin{array}{r}104 \\
74 \\
87 \\
87 \\
73 \\
82 \\
86 \\
105 \\
90 \\
97 \\
87 \\
87 \\
98 \\
116 \\
85\end{array}$ & $\begin{array}{l}217 \\
222 \\
226 \\
198 \\
192 \\
222 \\
225 \\
265 \\
273 \\
226 \\
211 \\
220 \\
244 \\
316 \\
249\end{array}$ & $\begin{array}{r}85 \\
62 \\
64 \\
53 \\
43 \\
113 \\
26 \\
47 \\
33 \\
78 \\
69 \\
30 \\
32 \\
3 \\
34\end{array}$ & $\begin{array}{l}302 \\
284 \\
290 \\
251 \\
235 \\
335 \\
251 \\
312 \\
306 \\
304 \\
280 \\
250 \\
276 \\
319 \\
283\end{array}$ \\
\hline $\begin{array}{l}\text { Average } \\
\text { Percentage } \\
\text { deficiency } \\
\% \text { Amount } \\
\text { supplied by }\end{array}$ & $\begin{array}{l}75 \cdot 7 \\
30 \\
84\end{array}$ & $\begin{array}{l}14 \cdot 8 \\
- \\
16\end{array}$ & $\begin{array}{l}90 \cdot 5 \\
16\end{array}$ & $\begin{array}{c}233 \cdot 7 \\
22 \\
82\end{array}$ & $\begin{array}{l}51 \cdot 4 \\
- \\
18\end{array}$ & $\begin{array}{c}285 \cdot 2 \\
4\end{array}$ \\
\hline
\end{tabular}

Calcium.-An average of $1.28 \mathrm{~g}$. per day with a range of 0.97 to $1.51 \mathrm{~g}$., indicates a deficiency in the diet of nursing mothers.

Vitamins.-Vitamin $A$ is seriously deficient in all diets. The average intake was 2,496 I.U. per head per day; the target demands 3,429 I.U. per head per day. The range was 1,886 to 3,750 I.U. per head per day: Only four hospitals could show an intake of over 3,000 I.U. daily, and only one hospital exceeded the target by 300 I.U.

Vitamin $B_{1}$. -The target requires $1.3 \mathrm{mg}$. per head per day, and the average was $1.37 \mathrm{mg}$. per head per day; the range was 1.09 to $1.80 \mathrm{mg}$. It should be noted that the figures were satisfactory because of the use of high-extraction flour. 
Vitamin $B_{2}$ (Riboflavin).-Target $2.4 \mathrm{mg}$; average $2.0 \mathrm{mg}$. per head per day; range 1.60 to $2 \cdot 43 \mathrm{mg}$.

Vitamin C.-The figures for vitamin $\mathrm{C}$ are of interest in that they are so markedly less than the N.R.C. requirements. As a result of the maximum amount of the vitamin that could possibly be secured by the suggested diet, the target was set at $36 \mathrm{mg}$. per head per day. Numerous dietary surveys of children and of members of the Forces have indicated that the generally accepted standard for this vitamin is probably far too high. One may criticize the target figure as too low: what can be said in defence of it is that it is about all one can secure in this land of austerity, and the surveys referred to do not entirely condemn it. The target of $36 \mathrm{mg}$. per head per day was almost attained, the average being $31.2 \mathrm{mg}$. per head per day. We may admit that the standard is somewhat austere, but the degree to which some hospitals have failed to reach it is interesting. Three large city hospitals and one smaller town hospital were above the target, which means that $74 \%$ of hospitals do not reach the target; neither of the rural hospitals reached it.

\section{FoOd SuPpled BY THE Hospitals}

Since the total nutrient consumption falls short of the target in almost every particular, it is obvious that the food supplied by the hospitals must do so to an even greater extent. The extent whereby diets are supplemented by gifts of food varies greatly, but nevertheless no patient in hospital should be dependent on extraneous food supplies. Apart from the fact that the food supplied by relatives and friends is or may be nutritively unbalanced, it is entirely wrong to rely upon such supplies. It should be the aim-as it is the duty-of all hospitals to supply the full quota of required nutrients.

Calories.-The average energy intake by food supplied by the hospitals was 1,914 Calories per day (Table III). The range was 1,495 to 2,647 Calories. The -range for a single day was tremendous, the highest being 3,002 Calories and the lowest 1,418 Calories. Out of 15 hospitals surveyed only one, a rural hospital of 30 beds, supplied a diet which exceeded the target for calories. In terms of possible patients in 873 beds in the hospitals examined, 30, i.e. $3 \cdot 4 \%$, received a diet supplying over 2,500 Calories per day. Four out of 15 hospitals gave over 2,000 Calories, which means that $73 \%$ of hospitals supplied, for their maternity patients, a diet containing less than 2,000 Calories (Table III). After a careful survey of diets as eaten daily for seven consecutive days by patients in the wards of 15 hospitals, it is fair comment to state that such figures are worthy of attention and point to a general inadequacy of dietary intake by far too many nursing mothers in the maternity wards of Scottish hospitals.

Protein.-The hospitals supplied on an average $75.1 \mathrm{~g}$. of total protein and $42.1 \mathrm{~g}$. of animal protein per head per day, the range being for total protein 58 to $100 \mathrm{~g}$., and for animal protein 28 to $54 \mathrm{~g}$. In terms of total protein, only one hospital gave in its dietary more than $99 \mathrm{~g}$. per head per day-the amount was $100 \mathrm{~g}$. It has been and still is very difficult to obtain sufficient amounts of animal 
protein. That no hospital reached the requirement of $60 \mathrm{~g}$. per head per day, that the average intake was $42 \cdot 1 \mathrm{~g}$., and the minimum $28 \mathrm{~g}$., indicate not only a serious deficiency in first-class protein but a faulty catering in certain hospitals. This statement is supported by the observation that, in $30 \%$ of the hospitals surveyed, nursing mothers received less than $\mathbf{4 0} \mathrm{g}$. of animal protein, and by the data in Table $\mathrm{V}$, where the number is given of patients in the hospitals in which the

TABLE VII

Chief Sources of Calcium (mg.) in Diets Supplied by Hospitals Target $=1.70 \mathrm{~g} . /$ Head $/$ day.

\begin{tabular}{|c|c|c|c|c|c|c|c|c|c|c|c|}
\hline No. & $\dot{z}$ & 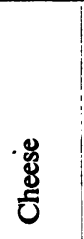 & 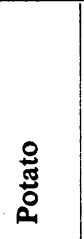 & 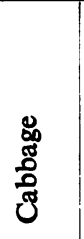 & 苨 & 总 & 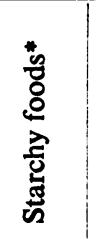 & 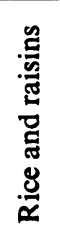 & 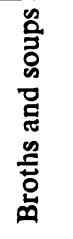 & & Total \\
\hline $\begin{array}{l}1 \\
2 \\
3\end{array}$ & $\begin{array}{l}969 \\
697 \\
950\end{array}$ & $\begin{array}{l}57 \\
24 \\
49\end{array}$ & $\begin{array}{l}7 \\
9 \\
5\end{array}$ & $\begin{array}{l}12 \\
13 \\
12\end{array}$ & $\begin{array}{l}69 \\
67 \\
88\end{array}$ & $\begin{array}{l}12 \\
12 \\
13\end{array}$ & $\begin{array}{l}56 \\
64 \\
60\end{array}$ & $\begin{array}{r}22 \\
9 \\
-\end{array}$ & $\begin{array}{l}43 \\
54 \\
45\end{array}$ & 二 & $\begin{array}{l}1,315 \\
1,007 \\
1,303\end{array}$ \\
\hline $\begin{array}{r}4 \\
5 \\
6 \\
7 \\
8 \\
9 \\
10 \\
11\end{array}$ & $\begin{array}{r}508 \\
720 \\
812 \\
636 \\
860 \\
708 \\
1,049 \\
953\end{array}$ & $\begin{array}{l}- \\
\bar{Z} \\
24 \\
48 \\
32 \\
16 \\
40\end{array}$ & $\begin{array}{r}6 \\
10 \\
5 \\
6 \\
8 \\
13 \\
6 \\
5\end{array}$ & $\begin{array}{r}\overline{-} \\
12 \\
12 \\
1 \\
7 \\
6 \\
5\end{array}$ & $\begin{array}{l}59 \\
76 \\
96 \\
70 \\
80 \\
91 \\
87 \\
75\end{array}$ & $\begin{array}{r}7 \\
7 \\
12 \\
13 \\
13 \\
14 \\
12\end{array}$ & $\begin{array}{r}80 \\
212 \\
96 \\
173 \\
172 \\
95 \\
123 \\
191\end{array}$ & $\begin{array}{l}\frac{26}{20} \\
\frac{24}{24} \\
-\end{array}$ & $\begin{array}{r}5 \\
70 \\
30 \\
37 \\
57 \\
76 \\
60 \\
69\end{array}$ & $\begin{array}{l}40 \\
= \\
= \\
= \\
=\end{array}$ & $\begin{array}{r}918 \\
1,273 \\
1,146 \\
1,114 \\
1,381 \\
1,145 \\
1,411 \\
1,381\end{array}$ \\
\hline $\begin{array}{l}12 \\
13\end{array}$ & $\begin{array}{l}674 \\
835\end{array}$ & $\overline{73}$ & $\begin{array}{l}6 \\
9\end{array}$ & $\begin{array}{l}3 \\
7\end{array}$ & $\begin{array}{l}71 \\
89\end{array}$ & $\begin{array}{l}10 \\
10\end{array}$ & $\begin{array}{l}45 \\
98\end{array}$ & 二 & $\begin{array}{l}47 \\
43\end{array}$ & $\begin{array}{c}\text { Ice cream } \\
41 \\
-\end{array}$ & $\begin{array}{r}933 \\
1,299\end{array}$ \\
\hline $\begin{array}{l}14 \\
15\end{array}$ & $\begin{array}{l}846 \\
836\end{array}$ & $\overline{24}$ & $\overline{5}$ & $\overline{8}$ & $\begin{array}{r}127 \\
94\end{array}$ & $\begin{array}{l}16 \\
11\end{array}$ & $\begin{array}{r}111 \\
85\end{array}$ & - & $\begin{array}{l}25 \\
53\end{array}$ & 324 & $\begin{array}{l}1,514 \\
1,363\end{array}$ \\
\hline $\begin{array}{l}\text { Av. } \\
\%\end{array}$ & $\begin{array}{r}803 \cdot 5 \\
65 \cdot 1\end{array}$ & $\begin{array}{r}25 \cdot 8 \\
2 \cdot 3\end{array}$ & $\begin{array}{l}6 \cdot 7 \\
0.54\end{array}$ & $\begin{array}{l}6 \cdot 5 \\
0.53\end{array}$ & $\begin{array}{c}82 \cdot 6 \\
6 \cdot 7\end{array}$ & $\begin{array}{c}10.4 \\
0.84\end{array}$ & $\begin{array}{r}110 \cdot 7 \\
9 \cdot 0\end{array}$ & & $\begin{array}{l}49 \\
4.0\end{array}$ & & $1,233 \cdot 5$ \\
\hline
\end{tabular}

* Starchy foods=cornflour, cocoa, semolina, chocolate mould, rice.

animal protein of the diet is above or below $40 \mathrm{~g}$. That $27 \cdot 2 \%$ of the patients in large city, and $15.3 \%$ in small town and rural hospitals received less than $40 \mathrm{~g}$., indicates the magnitude of the wartime deficiency in animal protein.

Fat.-The amount supplied averaged $75.7 \mathrm{~g}$. per head per day; the range was 42 to $114 \mathrm{~g}$.; with the exception of these two extremes the range was between 59 and $90 \mathrm{~g}$. of fat (Table VI). The hospitals have suffered, as have all in this country, from a deplorable lack of dietary fat. The $30 \%$ deficiency of fat in the hospital diet is, even for wartime conditions, too great. That patients' friends supplied $16 \%$ of the requirement of fat would indicate that the hospital deficiencies of $30 \%$ could certainly be lessened. 
Carbohydrate.-The average figure was $233.7 \mathrm{~g}$. per head per day; the range was 192 to $316 \mathrm{~g}$. The deficiency in the hospital supply is $22 \%$. The deficiency. in energy in terms of foods supplied by the hospitals is striking. None the less striking is the fact that the patients' friends and relatives supplied 16 and $18 \%$ respectively of the total intake of fat and carbohydrate (Table VI).

Minerals.-The average figures for calcium and iron were $1.23 \mathrm{~g}$. and $10.63 \mathrm{mg}$. per head per day respectively (Tables VII and VIII). The intake of these minerals was comparatively constant. The chief sources of calcium and iron as supplied

TABLE VIII

Chimf Sources of Iron In mg. In Diets Supplied by the Hospitals Target $=13 \mathrm{mg}$./headlday.

\begin{tabular}{|c|c|c|c|c|c|c|c|c|c|c|}
\hline No. & 总 & $\begin{array}{l}\text { 品 } \\
\text { 望 }\end{array}$ & $\sum_{\Sigma}^{\mathbb{\Xi}}$ & 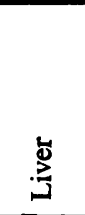 & 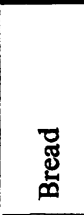 & $\begin{array}{c}\stackrel{8}{0} \\
\stackrel{0}{0} \\
\stackrel{0}{0}\end{array}$ & 胥 & ర్ర & 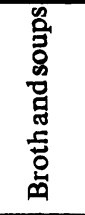 & Total \\
\hline $\begin{array}{r}1 \\
2 \\
3 \\
4 \\
5 \\
6 \\
7 \\
8 \\
9 \\
10 \\
11 \\
12 \\
13 \\
14 \\
15\end{array}$ & $\begin{array}{l}0.81 \\
0.58 \\
0.79 \\
0.51 \\
0.60 \\
0.69 \\
0.53 \\
0.72 \\
0.66 \\
0.87 \\
0.79 \\
0 \cdot 56 \\
0 \cdot 70 \\
0.71 \\
0.70\end{array}$ & $\begin{array}{l}0.42 \\
0.42 \\
0.82 \\
0.24 \\
0.92 \\
0.21 \\
2.02 \\
0.39 \\
0.55 \\
0.90 \\
0.80 \\
0.21 \\
0.21 \\
0.22 \\
0.54\end{array}$ & $\begin{array}{l}0.74 \\
0.82 \\
1.30 \\
0.93 \\
0.90 \\
0.68 \\
1.30 \\
0.88 \\
0.65 \\
1.10 \\
0.66 \\
0.79 \\
0.99 \\
1.43 \\
0.90\end{array}$ & $\begin{array}{l}.70 \\
= \\
= \\
= \\
0.97 \\
= \\
\overline{-} \\
1 \cdot 11 \\
0.83 \\
=\end{array}$ & $\begin{array}{l}1.71 \\
1.65 \\
2.17 \\
1.45 \\
1.90 \\
2.35 \\
1.74 \\
2.27 \\
2.56 \\
2.10 \\
1.83 \\
1.75 \\
2.19 \\
3.12 \\
2.53\end{array}$ & $\begin{array}{l}0.90 \\
0.89 \\
1.01 \\
- \\
0.50 \\
0.88 \\
0.99 . \\
1.82 \\
1.00 \\
1.05 \\
0.88 \\
0.73 \\
0.75 \\
2.49 \\
0.84\end{array}$ & $\begin{array}{l}0.55 \\
0.76 \\
0.42 \\
0.50 \\
0.87 \\
0.43 \\
0.55 \\
0.57 \\
1.08 \\
0.49 \\
0.39 \\
0.05 \\
0.80 \\
0.60 \\
0.44\end{array}$ & $\begin{array}{l}1.71 \\
2.00 \\
1.29 \\
0.72 \\
-\overline{17} \\
\overline{-} \\
0.57 \\
0.29 \\
= \\
= \\
\overline{-} \\
0.72 \\
0.57\end{array}$ & $\begin{array}{l}2 \cdot 10 \\
1.71 \\
1.45 \\
0 \cdot 10 \\
3.00 \\
1.81 \\
1.59 \\
2.59 \\
2.71 \\
2 \cdot 11 \\
2.54 \\
1.60 \\
1.17 \\
0.75 \\
1.97\end{array}$ & $\begin{array}{r}11.47 \\
10.60 \\
10.33 \\
9.03 \\
9.80 \\
7.70 \\
13.00 \\
13.00 \\
10.80 \\
10.04 \\
8.61 \\
9.32 \\
13.22 \\
12.50 \\
10.42\end{array}$ \\
\hline $\begin{array}{l}\text { Average } \\
\text { Percentage }\end{array}$ & $\begin{array}{l}0.68 \\
6.4\end{array}$ & $\begin{array}{l}0.64 \\
6 \cdot 1\end{array}$ & $\begin{array}{l}0.94 \\
8 \cdot 3\end{array}$ & & $\begin{array}{c}2 \cdot 10 \\
19 \cdot 8\end{array}$ & $\begin{array}{l}0 \cdot 78 \\
7 \cdot 3\end{array}$ & $\begin{array}{l}0 \cdot 57 \\
5 \cdot 4\end{array}$ & & $\begin{array}{l}1 \cdot 80 \\
1 \cdot 7\end{array}$ & $10 \cdot 63$ \\
\hline
\end{tabular}

by the hospital diets are shown in Tables VII and VIII. The supreme importance of milk as a source of calcium is shown in Table VI; the value of liver, eggs, national bread, and potatoes as sources of iron is shown in Table VIII. It is worthy of note that milk, in adequate amount, cannot be ignored as a source of iron: two pints of milk $(1,150 \mathrm{~g}$.) will give $1 \cdot 15 \mathrm{mg}$. of iron. The best source of iron is national bread. The value of a combination of milk and cocoa should be noted.

Vitamins.-Vitamin A.-The target for vitamin A is 3,429 I.U. per head per day. The average amount of vitamin A supplied in hospital diets was 2,266 I.U. per head per day; the range was 1,621 to 3,212 I.U. No hospital reached the target, the largest intake in any one day being 3,313 I.U., the lowest 1,232 I.U. The greatest deficiencies were in the large city hospitals, in two of which 1,711 and 1,621 I.U. per head per day were supplied. The chief sources of this vitamin as supplied in 
hospital diets are milk, butter, margarine, and carrots (Table XI). The deficiency in vitamin A indicates the need for more milk, fats, and vegetables, particularly carrots. The value of sheep's liver as a source is so important that every effort should be made to increase the amount of liver in the diets of nursing mothers.

Vitamin $B_{1}$.-With an average intake of $1.25 \mathrm{mg}$., vitamin $B_{1}$ was satisfactory.

TABLE IX

Chief Sources of Vitamin A (I.U.) in Diets Supplifd by Hospitals

Target $=3,429$ I.U.

\begin{tabular}{|c|c|c|c|c|c|c|c|c|c|c|c|}
\hline No. & 总 & $\begin{array}{l}\text { 号 } \\
\text { 总 } \\
\text { 营 }\end{array}$ & 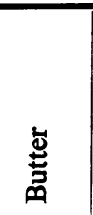 & $\begin{array}{l}\text { 是 } \\
\text { 严 }\end{array}$ & $\begin{array}{l}\text { ष्ठ } \\
\text { త్ }\end{array}$ & 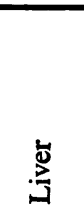 & 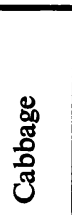 & 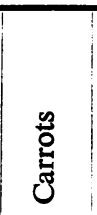 & 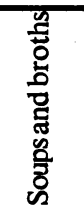 & 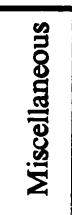 & Total \\
\hline $\begin{array}{r}1 \\
2 \\
3 \\
4 \\
5 \\
6 \\
7 \\
8 \\
9 \\
10 \\
11 \\
12 \\
13 \\
14 \\
15\end{array}$ & $\begin{array}{r}565 \\
813 \\
554 \\
360 \\
840 \\
678 \\
742 \\
1,004 \\
413 \\
612 \\
1,112 \\
787 \\
474 \\
494 \\
976\end{array}$ & $\begin{array}{l}256 \\
208 \\
384 \\
288 \\
304 \\
-208 \\
288 \\
297 \\
240 \\
224 \\
240 \\
208 \\
528 \\
324\end{array}$ & $\begin{array}{c}160 \\
100 \\
\overline{160} \\
120 \\
\overline{140} \\
160 \\
160 \\
\overline{80} \\
100 \\
200 \\
240 \\
260\end{array}$ & $\begin{array}{r}123 \\
123 \\
118 \\
261 \\
280 \\
62 \\
529 \\
116 \\
266 \\
263 \\
264 \\
62 \\
62 \\
75 \\
159\end{array}$ & $\begin{array}{l}91 \\
39 \\
78 \\
- \\
- \\
\frac{39}{78} \\
52 \\
26 \\
65 \\
\frac{117}{39}\end{array}$ & $\begin{array}{l}750 \\
\overline{-} \\
= \\
\overline{-} \\
\overline{1,050} \\
\overline{-} \\
\overline{1} \\
1,200 \\
\overline{900} \\
=\end{array}$ & $\begin{array}{l}78 \\
60 \\
75 \\
- \\
48 \\
81 \\
45 \\
42 \\
33 \\
21 \\
45 \\
\frac{51}{51}\end{array}$ & $\begin{array}{c}\overline{-} \\
1,133 \\
363 \\
800 \\
533 \\
- \\
- \\
\overline{-} \\
\overline{1} \\
\frac{107}{E} \\
-\end{array}$ & $\begin{array}{r}39 \\
233 \\
210 \\
53 \\
103 \\
147 \\
48 \\
142 \\
176 \\
190 \\
167 \\
160 \\
281 \\
140 \\
121\end{array}$ & $\begin{array}{r}84 \\
179 \\
73 \\
226 \\
279 \\
53 \\
371 \\
374 \\
243 \\
507 \\
227 \\
139 \\
822 \\
456 \\
784\end{array}$ & $\begin{array}{l}2,146 \\
1,755 \\
2,635 \\
1,711 \\
2,726 \\
1,621 \\
2,158 \\
3,212 \\
1,652 \\
1,881 \\
2,172 \\
2,836 \\
2,914 \\
1,863 \\
2,714\end{array}$ \\
\hline $\begin{array}{l}\text { Average } \\
\text { Percentage }\end{array}$ & $\begin{array}{r}694 \cdot 9 \\
30 \cdot 7\end{array}$ & $\begin{array}{r}266 \cdot 5 \\
11 \cdot 8\end{array}$ & $\begin{array}{r}125 \cdot 3 \\
5 \cdot 5\end{array}$ & $\begin{array}{r}184 \cdot 2 \\
8 \cdot 1\end{array}$ & $\begin{array}{r}41 \cdot 6 \\
1 \cdot 8\end{array}$ & & $\begin{array}{r}38 \cdot 6 \\
1.7\end{array}$ & $\begin{array}{r}195.8 \\
8.6\end{array}$ & $\begin{array}{r}147 \cdot 3 \\
6 \cdot 5\end{array}$ & & 2,266 \\
\hline
\end{tabular}

Note.-The larger variations in the vitamin A content of milk are due to the difference between summer and winter supply.

Vitamin C.-With $23.5 \mathrm{mg}$. per head per day as the average intake, vitamin C was far short of the target requirement of $36 \mathrm{mg}$. per head per day. The amount of vitamin $\mathrm{C}$ in hospital diets was, even in terms of the target, far too low in the majority of the hospital diets examined (Table X). Two hospitals passed the target figure, one by $2 \mathrm{mg}$. the other by $17 \mathrm{mg}$. That with a ration of oranges two hospitals-and the only two which were in receipt of this ration at the time of survey-should fail to reach the target is comment enough on the need for dietetic advice and supervision of hospital diets. The aim must be to increase the supply of milk, green vegetables, potatoes and fruit, particularly oranges. 


\section{Food Contributed by Patients' Relatives and Friends}

While relatives and friends of the patients contributed little protein, they did supply a considerable percentage of the total fat and carbohydrate consumed: this was particularly true of the large city hospitals (see Table VI). Table VI

TABLE $X$

Chief Sources of Vitamin C (mg.) In Diets Supplied by Hospitals

Target $=36 \mathrm{mg}$./head/day.

\begin{tabular}{|c|c|c|c|c|c|c|c|}
\hline No. & Milk & Potato & Cabbage & $\begin{array}{c}\text { Green } \\
\text { Vegetable }\end{array}$ & $\begin{array}{l}\text { Broths and } \\
\text { soups }\end{array}$ & Oranges & Total \\
\hline $\begin{array}{r}1 \\
2 \\
3 \\
4 \\
5 \\
6 \\
7 \\
8 \\
9 \\
10 \\
11 \\
12 \\
13 \\
14 \\
15\end{array}$ & $\begin{array}{c}5 \\
7 \\
9 \\
9 \cdot 5 \\
5 \\
5 \\
10 \\
7 \cdot 5 \\
6 \\
13 \\
18 \cdot 5 \\
6 \\
14 \cdot 5 \\
11 \cdot 8 \\
10 \\
10 \cdot 5\end{array}$ & $\begin{array}{c}3 \\
21 \\
3 \\
1 \\
2 \cdot 5 \\
2 \cdot 5 \\
2 \\
4 \\
3 \\
3 \cdot 5 \\
2 \\
28 \\
8 \\
8 \\
4 \cdot 5\end{array}$ & $\begin{array}{l}2 \\
6 \\
-1 \\
1 \\
0 \cdot 5 \\
-6 \\
6 \cdot 5 \\
0 \cdot 5 \\
4 \cdot 5 \\
8 \\
2 \cdot 5 \\
1 \\
-4\end{array}$ & $\begin{array}{l}2 \\
2 \cdot 5 \\
1 \cdot 5 \\
2 \cdot 5 \\
2 \\
3 \cdot 5 \\
2 \\
1 \cdot 5 \\
6 \cdot 5 \\
1 \\
5 \\
1 \cdot 4 \\
\frac{6}{6}\end{array}$ & $\begin{array}{l}3 \\
1 \cdot 5 \\
4 \\
2 \\
0 \cdot 5 \\
1 \cdot 5 \\
1 \\
0 \cdot 5 \\
0 \cdot 5 \\
2 \\
3 \\
3 \\
3 \cdot 5 \\
4 \\
3\end{array}$ & $\begin{array}{l}= \\
= \\
= \\
= \\
\overline{5} \\
5 \\
= \\
= \\
=\end{array}$ & $\begin{array}{l}15 \\
38 \\
16 \\
10 \\
11 \\
16 \\
20 \\
18 \\
25 \\
35 \\
20 \\
53 \\
26 \\
22 \\
28\end{array}$ \\
\hline $\begin{array}{l}\text { Average } \\
\text { Percentage }\end{array}$ & $\begin{array}{r}9 \cdot 2 \\
39 \cdot 1\end{array}$ & $\begin{array}{r}6 \cdot 4 \\
27 \cdot 2\end{array}$ & $\begin{array}{r}2 \cdot 5 \\
10 \cdot 6\end{array}$ & $\begin{array}{r}2 \cdot 5 \\
10 \cdot 6\end{array}$ & $\begin{array}{l}2 \cdot 2 \\
9 \cdot 4\end{array}$ & & $23 \cdot 5$ \\
\hline
\end{tabular}

TABLE XI

Milk in Pints per Head per Day in Maternity Hospitals

Priority: nursing mothers $=1$ pint per head per day. Non-priority ration $=0.5$ pint per head per day. 1 pint $=568$ c.cm.

\begin{tabular}{c|c|c|c}
\hline No. & Large cities & No. & Small towns \\
\hline 1 & 1.42 & 7 & 0.94 \\
2 & 1.02 & 8 & 1.25 \\
3 & 1.40 & 12 & 1.00 \\
4 & 0.89 & 13 & 1.22 \\
5 & 1.04 & & \\
6 & 1.19 & 14 & Rural areas \\
9 & 1.08 & 15 & 1.24 \\
10 & 1.40 & 1.23 \\
\hline
\end{tabular}

shows that the patients supply $16 \%$ of the total intake of fat and $18 \%$ of carbohydrate. In terms of calories this extraneous supply varied greatly, ranging from 32 to 862 Calories per head per day, with an average of 370.3 Calories per head 
per day. With the exception of vitamin $\mathrm{C}$, which depends so much on the availability of fruit, the supply of other nutrients was of no significance. The only source of animal protein supplied by friends was eggs, 0.36 egg per head per day, equal to $2 \cdot 16 \mathrm{~g}$. protein.

\section{The Chief Deficiencies and the Means for their Improvement} Milk

The outstanding contribution which milk makes in supplying animal protein, calcium, and vitamins $A, B_{1}$, and riboflavin has been emphasized. Most hospitals supply one pint of milk per head per day, and it would appear from Table XI that, in respect of milk, the location of the hospital plays no very significant part:

TABLE XII

A Comparison of the Calories and Nutrients in Hospital Diets: in One Pint of Milk: AND IN THE SUGGeSTED DIET

\begin{tabular}{|c|c|c|c|c|c|c|}
\hline & Calories & $\begin{array}{c}\text { Total } \\
\text { protein } \\
\text { g. }\end{array}$ & $\begin{array}{l}\text { Animal } \\
\text { protein } \\
\mathbf{g} .\end{array}$ & $\begin{array}{l}\text { Fat } \\
\text { g. }\end{array}$ & $\begin{array}{l}\text { Calcium } \\
\text { g. }\end{array}$ & $\begin{array}{l}\text { Vitamin A } \\
\text { I.U. }\end{array}$ \\
\hline $\begin{array}{cccc}\text { Hospital diet } & \text { average } & \text { per } \\
\text { day } & \ldots & \ldots & \ldots\end{array}$ & 1,914 & $75 \cdot 1$ & $42 \cdot 1$ & $75 \cdot 7$ & $1 \cdot 23$ & 2,096 \\
\hline 1 pint of milk (extra) & 360 & $19 \cdot 0$ & $19 \cdot 0$ & $21 \cdot 0$ & $0: 68$ & 800 \\
\hline Total & 2,274 & $94 \cdot 1$ & $61 \cdot 1$ & $96 \cdot 7$ & $1 \cdot 91$ & 2,896 \\
\hline The Target & 2,500 & 99 & 60 & 108 & $1 \cdot 70$ & 3,429 \\
\hline
\end{tabular}

four out of nine large city hospitals gave more than the rural and small town hospitals. The average amount of milk in the hospital diets was $1 \cdot 18$ pints of milk per head per day. In view of the serious deficiency of animal protein, fat and vitamin $A$, it is evident that nursing mothers should have, in whatever form it may be most acceptable to them, two pints of milk per day: this ought to be a dietetic axiom for maternity hospitals. This requires that hospital staffs and the patients should be informed of the value of milk and nursing mothers should be encouraged to take the full amount.

In Table XII, the calories, total and animal protein, fat, calcium and vitamin $\mathbf{A}$ of the hospital diet are compared with the content of these nutrients in one pint of milk, the diet, to which one pint of milk has been added, and the target. The means of further increasing the calories, minerals and vitamins will readily come to mind: for example, butter, eggs, cheese, liver, potatoes, etc. The data in Tables VII to XI, showing the chief sources of minerals and vitamins in hospital diets, indicate those foodstuffs the increased use of which will make for dietary improvements. It is hoped that the serious protein and vitamin A deficiencies will be reduced in the near future by a greater supply of milk, bacon, eggs and liver. 
Until then, and even then, concentrates of vitamins A and D, as cod liver oil, vitamin . C-in the form of orange juice-and extract of rose hips must be given to all nursing mothers. This is not said without some knowledge of the difficulties in persuading not a few to take capsules of vitamin $A$ and $D$ and orange juice. There is no reason why orange juice should be presented in any but an attractive form. The serious deficiency of vitamin $\mathrm{C}$ can be partly made good by a greater use of green vegetables and potatoes properly cooked and speedily served. The value of fish, particularly fatty fish, as a source of animal protein and vitamins should not be overlooked. A greater variation in the design and presentation of diets would do much to increase the amount of nutrients and, stimulating appetite, encourage a greater intake of food.

While criticism of not a few hospital dietaries cannot be evaded, the main import of such an investigation is to indicate the deficiencies and the means for their relief. In the unprecedented difficulties which have dogged the steps of all who cater, be it for large or small groups, it is remarkable that the deficiencies have not been much greater. To maintain a satisfactory dietary for patients in maternity wards of hospitals it is necessary to have dietitians responsible for ordering foodstuffs, framing menus, management and control of kitchens, and for the supervision of all diets-general and special. Only by the appointment of dietitians in all large hospitals, as also for groups of smaller hospitals, can the principles of nutrition be adequately translated into the practice of hospital dietetics.

We should like to take this opportunity to thank Miss Adamson for the excellent manner in which she carried out the dietary surveys in the maternity wards of the fifteen hospitals investigated, and also the Medical Officers of Health, Medical Superintendents, Matrons, and Ward Sisters for their interest and helpful co-operation in the work. We wish, too, to thank the Scientific Advisory Committee and Sir Andrew Davidson, Chief Medical Officer of the Department of Health for Scotland, for permission to publish the results of this survey. 